U. S. DEPARTMENT OF COMMERCE BUREAU OF STANDARDS

\title{
PLATE GLASS MIRRORS
}

\section{COMMERCIAL STANDARD CS27-30}

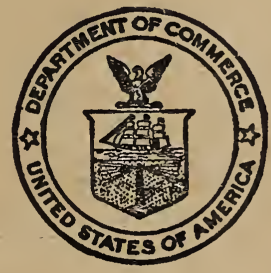

ELIMINATION OF WASTE Through SIMPLIFIED COMMERCIAL PRACTICE 
Below are described some of the series of publications of the Department of Commerce which deal with various phases of waste elimination.

\section{Simplified Practice Recommendations.}

These present in detail the development of programs to eliminate unnecessary variety in sizes, dimensions, styles, and types of over 100 commodities. They also contain lists of associations and individuals who have indicated their intention to adhere to the recommendations. These simplified schedules, as formulated and approved by the industries, are indorsed by the Department of Commerce.

Commercial Standards.

These are developed by various industries under a procedure similar to that of simplified practice recommendations. They are, however primarily concerned with considerations of grade, quality, and such other characteristics as are out side the scope of dimensional simplification.

American Marine Standards.

These are promulgated by the American Marine Standards Committee, which is controlled by the marine industry and administered as a unit of the division of simplified practice. Their object is to promote economy in construction, equipment, maintenance, and operation of ships. In general, they provide for simplification and improvement of design, interchangeability of parts, and minimum requisites of quality for efficient and safe operation.

Lists of the publications in each of the above series can be obtained by applying to the National Bureau of Standards, Washington, D.C. 


\section{U. S. DEPARTMENT OF COMMERCE}

R.P. LAMONT, Secretary

BUREAU OF STANDARDS

GEORGE K. BURGESS, Director

\section{PLATE GLASS MIRRORS}

\section{COMMERCIAL STANDARD C\$27-30}

Effective Date for New Production December 15, 1930

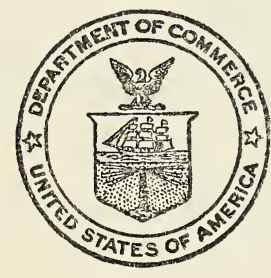

UNITED STATES

GOVERNMENT PRINTING OFFICE

WASHINGTON : 1931 


\section{CONTENTS}

Acceptors - . - . -

Commercial Standard CS27-30

General conference

Export trade

Standing committee and effective date

Certification plan

Commercial standards service.

Organization and duties of standing committee

Your cooperation

Acceptance of commercial standard

To the acceptor

Request for commercial standards

List of commercial standards. 


\section{ACCEPTORS}

\section{ASSOCIATIONS}

American Home Economics Association, Washington, D. C.

American Hotel Association, New York, N. Y.

American Specification Institute, Chicago, IIl.

Architects' Small House Service Bureau (Inc.), The, Minneapolis, Minn. (in principle).

National Association of Furniture Manufacturers (Inc.), Chicago, Ill.

National Retail Furniture Association, Chicago, Ill.

New England Council, Boston, Mass. (in principle).

\section{FIRMS}

Abeles Glass Co., The, Little Rock, Ark.

Abrams Co., J., Chicago, Ill.

Acme Specialty Manufacturing Co., The, Toledo, Ohio.

Akron Mirror \& Glass Co., The, Akron, Ohio.

American Enameled Products Co., Mount Pleasant, Mich.

American Fixture \& Showcase Manufacturing Co., St. Louis, Mo.

American Furniture Co., Denver, Colo.

American Glass \& Construction Co., Rochester, N. Y.

American Mirror Co., Providence, R. I. American Mirror Works, Butler, $\mathrm{Pa}$.

American Plate Glass Corporation, Kane, $\mathrm{Pa}$.

Anderson \& Co., Geo. H., Chicago, Ill.

Angelus Furniture Manufacturing Co., Los Angeles, Calif.

Art Metal Construction Co., Jamestown, N. Y.

Austell Cabinet Co., Austell, Ga.

Badger Mirror Co., Milwaukee, Wis.

Bassett Mirror Co., Bassett, Va.

Beacon Plate \& Window Glass Co., Brookline, Mass.

Beardsley Glass \& Glazing Co., Rochester, N. Y.

Behm \& Sons Co., The George, Dayton, Ohio.

Belknap Glass Co., C. C., Seattle, Wash.

Bendit Drey Co., (Inc.), Brooklyn, N. Y.

Berkey Furniture Co., Wm. A., Grand Rapids, Mich.

Berkowitz, J. E., Philadelphia, Pa.

Betz Co., Frank S., Hammond, Ind.

Binswanger \& Co. of Tennessee, Memphis, Tenn.
Birmingham Paint \& Glass Co., Birmingham, Ala.

Blue Ridge Glass Corporation, Kingsport, Tenn.

Boehm Cabinet Co., The J., Cleveland, Ohio.

Boher \& Hosfeld, Shippensburg, $\mathrm{Pa}$.

Boston Mirror Co., Boston, Mass.

Broude Co., W. S., Chicago, Ill.

Cadillac Glass Co., Detroit, Mich.

Caldwell \& Co. (Inc.), Edward F., New York, N. Y.

California Glass Co., Los Angeles, Calif.

Cameron \& Co. (Inc.), Wm., Waco, Tex.

Capitol Glass \& Mirror Co., Baltimore, Md.

Central Furniture Manufacturing Co., Los Angeles, Calif.

Central Glass Co., Louisville, $\mathrm{Ky}$.

Central Glass Co. of Virginia, Bristol, $\mathrm{Va}$.

Central Specialty Manufacturing Co., Chicago, Ill.

Charlotte Furniture Co., Charlotte, Mich.

Chaudron \& Co., Baltimore, Md.

Churchill Cabinet Co., Chicago, Ill.

Cobbledick-Kibbe Glass Co., Oakland, Calif.

Condie-Bray Glass \& Paint Co., St. Louis, Mo.

Conrad Co., H. G., Chicago, Ill. (in principle).

Consolidated Mirror Co., High Point, N. C.

Cooledge \& Sons, F. J., Atlanta, Ga.

Cornell University, Ithaca, N. Y. (in principle.)

Cron Kills Co., The, Piqua, Ohio.

Crowe Glass Co., San Francisco, Calif.

Crystal Mirror \& Glass Co., St. Louis, Mo.

Culver Art \& Frame Co., The, Westerville, Ohio.

Curtis Publishing Co., Cleveland, Ohio (in principle).

Dame Furniture Co., Harriman, Tenn.

Dauchy Co., Chas. H., Troy, N. Y.

Dearborn Glass Co., Chicago, Ill.

Decorators Furniture Co., (Inc.), New York, N. Y.

Denier Mirror \& Plate Glass Co., (Inc.), West New York, N. J.

Detroit Show Case Co., Detroit, Mich.

Dixie Metal Products Co., Birmingham, Ala.

Donnelly Kelley Glass Co., Holland, Mich.

Eagle Convex Glass Specialty Co., Clarksburg, W. Va. 
Easton Furniture Manufacturing Co., Easton, Md.

East Tennessee Woodworking Co., Morristown, Tenn.

Eberhardt Co., H., Chicago, Ill.

Ecker Co., Ferd., High Point, N. C.

Edmonds \& Co., Thos. C., New York, N. Y.

Ehlert Co., The H. F., Cleveland, Ohio.

Electrical Testing Laboratories, New York, N. Y.

Elias \& Co. (Inc.), Joseph, Long Island City, N. Y.

Elmira Mirror Works, Elmira, N. Y.

Emerson Glass Corporation, Jamestown, N. Y.

Empire (Ltd.), The, Rockford, Ill.

Esser Co., T. C., Milwaukee, Wis.

Estey Manufacturing Co., Owosso, Mich.

Eureka Glass Works (Inc.), Brooklyn, N.Y.

Excel Metal Cabinet Co. (Inc.), Jamestown, N. Y.

Falconer Plate Glass Corporation, Falconer, N. Y.

Famous-Barr Co., St. Louis, Mo.

Fargo Glass \& Paint Co., Fargo, N. Dak.

Farley \& Loetscher Manufacturing Co., Dubuque, Iowa (in principle).

Ficks \& Co., (Inc.), Chicago, Ill.

Fisher Manufacturing \& Fuel Co., Wilmington, Ohio.

Fitzgibbon, Geo. H., Portland, Oreg.

Forman, Ford \& Co., Minneapolis, Minn.

Fort Wayne Mirror Works, Fort Wayne, Ind.

Foster \& Bro. Co., Theodore W., Providence, R. I.

Franklin Glass \& Mirror Co., Chicago, Ill.

French Mirror Co., New York, N. Y.

Fuller \& Co., W. P., San Francisco, Calif.

Galax Mirror Co., Galax, Va.

Garden City Mirror \& Shock Works, Chicago, Ill.

Gates' Sons Co., J. M., Charleston, W. Va.

Gillis Co., J. W., Rochester, N. Y.

Gist Cabinet Co. (Inc.), Kansas City, Mo.

Glenny Glass Co., The Wm., Cincinnati, Ohio.

Globe Bosse World Furniture Co., Evansville, Ind.

Gould Novelty Co., Philadelphia, Pa. Graham Co., Carl (glass division), Wichita, Kans.

Grand Rapids Furniture Co., Grand Rapids, Mich.

Habenicht \& Howlett, San Francisco, Calif.

Haberer Furniture Co., J. E., Lowville, N. Y.

Hagemann Bros. Co., Cincinnati, Ohio.

Harmon \& Co., F. S., Tacoma, Wash.

Hart Mirror Plate Co., Grand Rapids, Mich.
Haskew Manufacturing Co., Morristown, Tenn.

Hickmann Bros. (Inc.), Brooklyn, N. Y. Hires Turner Glass Co., Philadelphia, $\mathrm{Pa}$.

Holtzman \& Sons Co., The Henry, Columbus, Ohio.

Home Furniture Co., York, Pa.

Hubbuch Glass Co., Chattanooga, Tenn.

Hub Furniture Co., Fort Worth, Tex. Huttig Sash \& Door Co., St. Louis, Mo. Illinois Cut Glass \& Mirror Works, Chicago, Ill.

Indiana Mirror Manufacturing Co., Indianapolis, Ind.

Indianapolis Paint \& Color Co., Indianapolis, Ind.

Joerns Bros. Furniture Co., Stevens Point, Wis.

Johnson-Gustafson, Duluth, Minn.

Johnston Glass Co., The, Hartford City, Ind.

Jonas Manufacturing Co., Lenoir, N. C.

Kahn Mirror Plate Co., St. Louis, Mo.

Kayser \& Allman, Philadelphia, Pa. (in principle).

Kellman Glass \& Mirror Co., Chicago, Ill.

Kinsella Co., John J., Chicago, Ill.

Kittinger Co., Buffalo, N. Y.

Klerner Furniture Co., Peter, New Albany, Ind.

Kompass \& Stoll Co., The, Niles, Mich. Krakovitz \& Sons Co., M., Philadelphia. $\mathrm{Pa}$.

Krieg-Mellen Furniture Co., Indianapolis, Ind.

Lansburgh \& Bro., Washington, D. C.

Lawson Co., The F. H., Cincinnati, Ohio.

Leeds \& Northrup Co., Philadelphia, $\mathrm{Pa}$. (in principle).

Leonardo Co. (Inc.), The, New York, N. Y.

Libbey-Owens-Ford Glass Co., Toledo, Ohio.

Liberty Mirror Works, Brackenridge, $\mathrm{Pa}$.

Max \& Sons, Lewis, Jersey City, N. J.

Melnick, Abraham, New York, N. Y.

Metropolitan Picture Frame Co., Chicago, Ill. (in principle).

Michigan State College, East Lansing, Mich.

Miller Furniture Co., Herman, Zeeland, Mich.

Milwaukee Mirror \& Art Glass Works, Milwaukee, Wis.

Montgomery Table \& Desk Works, Montgomery, $\mathrm{Pa}$.

Morgan Millwork Co., Baltimore, Md.

Morton Manufacturing Co., Chicago, Ill.

Mueller Bros. Art \& Manufacturing Co., Chicago, Ill.

Mueller Bros. (Inc.), Chicago, Ill.

Munago Co. (Inc.), The, Chicago, Ill. 
National Mirror Co., Buffalo, N. Y.

Nelson Manufacturing Co., N. O., St. Louis, Mo.

Newport Glass \& Mirror Co., Newport, $\mathrm{Ky}$.

Niepolds' (Inc.), Washington, D. C.

Northwestern Glass Co., Minneapolis, Minn.

Nurre Companies, The, Bloomington, Ind.

Ohio Plate Glass Co., Toledo, Ohio.

Ohio Window Glass Co., Cleveland, Ohio.

Olson Co., J. A., Chicago, Ill.

Oneidacraft (Inc.), Oneida, N. Y.

Original Picture Frame Co., Scranton, $\mathrm{Pa}$.

Oshkosh Mirror Plate Co., Oshkosh, Wis.

Pacific Door \& Sash Co., Los Angeles, Calif.

Par-Metal Products Corporation, Long Island City, N. Y.

Paschal Miner Co., Winston-Salem, N. C.

Patek Bros. (Inc.), Milwaukee, Wis.

Penn Plate Glass \& Mirror Co. (Inc.), Philadelphia, Pa.

Perry Paint \& Glass Co., Tampa, Fla.

Phenix Furniture Co., Warren, Pa.

Pittsburgh Plate Glass Co., Pittsburgh, $\mathrm{Pa}$.

Postlewait Glass Co., Kansas City, Mo.

Premier Cabinet Corporation, Jamestown, N. Y.

Pringle Furniture Co., Detroit, Mich.

Raphael Glass Co., Los Angeles, Calif.

Red Lion Furniture Co., Red Lion, Pa.

Richard Manufacturing Co., Winooski, Vt.

Rock, William, Baltimore, Md.

Rockford Palace Furniture Co., Rockford, Ill.

Rockford Republic Furniture Co., Rockford. Ill.

Rodgers-Wade Furniture Co., Paris, Tex.

Roe-James Glass Co., St. Paul, Minn.

Rosenthal (Inc.), P., Philadelphia, Pa.

Saginaw Furniture Shops, Saginaw, W. S., Mich.

Schwabacher Frey Co., San Francisco, Calif.

Simpson-Clark Glass Co., Chicago, Ill.

Sioux Falls Paint \& Glass Co., Sioux Falls, S. Dak.

Slack \& Co., I. N., New York, N. Y.

Slane Glass Co., O. W., Statesville, N. C.

Smith Manufacturing Co., Geo., Chicago, Ill.

Spencer Cardinal Corporation, Marion, Ind.

Standard Glass \& Paint Co., Des Moines, Iowa.

Standard Mirror Co. (Inc.), Buffalo, N. $Y$.

Star Furniture Co., Jamestown, N. Y.
Steel \& Wike Co., Philadelphia, Pa.

Steul \& Sons (Inc.), Henry C., Buffalo, N. Y.

Stickley Bros. Co., Grand Rapids, Mich.

Stockwell-Kling Corporation, Los Angeles, Calif.

Stott-Hecht Glass Works, Philadelphia, $\mathrm{Pa}$.

Strawbridge \& Clothier, Philadelphia, $\mathrm{Pa}$.

Sweat-Comings Co., The, Richford, Vt.

Swindell Bros., Baltimore, Md.

Syracuse Glass Co., Syracuse, N. Y.

Thompson Glass \& Paint Co., Los Angeles, Calif.

Toledo Mirror-Paint \& Glass Co., The, Toledo, Ohio.

Tyler \& Hippach (Inc.), Chicago, Ill.

Tyre Bros. Glass Co., San Francisco, Calif.

Union Furniture Co., Jamestown, N. Y.

Union Mirror Co., Lenoir, N. C.

University of California, Berkeley, Calif.

University of Illinois, Urbana, Ill.

University of Utah, Salt Lake City, Utah.

University of Wyoming, Laramie, Wyo.

Van Gilder Glass Co., W. A., Knoxville, Tenn.

Virginia Mirror Co., Martinsville, Va.

Vogeley \& Lackman Co. (Inc.), New York, N. Y.

Walsh-Coffey Glass Co., St. Louis, Mo.

Warren Co. (Inc.), The, Atlanta, Ga.

Warren Mirror Works, Warren, Pa.

Waxman \& Co., A., Philadelphia, Pa.

Weigelt Glass \& Mirror Manufacturing Co. (Inc.), St. Louis, Mo.

Werbelovsky's Son, J. H., Brooklyn, N. Y.

Western Furniture Co., Indianapolis, Ind.

Wigren-Lawrence Glass Co., Los Angeles, Calif.

Williamsport Mirror \& Glass Co., Williamsport, $\mathrm{Pa}$.

Winnebago Manufacturing Co., Rockford IIl.

Wisconsin Furniture Co. Milwaukee, Wis.

Wisconsin Mirror Plate Co., Sheboygan, Wis.

Wolfe Bros. \& Co., Piney Flats, Tenn.

Wood Glass Co., Syracuse, N. Y.

York Mirror \& Glass Co., York, Pa.

Youngsville Mirror Works, Youngsville, $\mathrm{Pa}$.

Zummach, William F., Milwaukee, Wis.

\section{GOVERNMENT}

Government of the District of Columbia, purchasing officer, Washington, D. C. 



\section{PLATE GLASS MIRRORS}

\section{COMMERCIAL STANDARD CS27-30}

On June 12, 1930, a joint conference of representative manufacturers, distributors, and users of plate glass mirrors adopted a commercial standard for that commodity. The industry has since accepted and approved for promulgation by the Department of Commerce the specification as shown herein.

The standard is effective for new production December 15, 1930.

Promulgation recommended.

I. J. FAIRChILD,

Promulgated. Chief, Divisicn of Trade Standards.

Approved.

George K. Burgess, Directcr, Bureau of Standards.

R. P. LAMONT.

Secretary of Commerce. 


\section{COMMERCIAL STANDARD CS27-30}

\section{PURPOSE}

These standards of quality are established as a basis of common understanding for the industry. By their adoption it is hoped that interest may be revived in the use of better quality mirrors, and that shipping costs, packing charges, and other expenses incident to exchanged merchandise, which occur through misunderstandings between buyer and seller may be eliminated.

\section{SCOPE}

This commercial standard covers plate glass mirrors of five distinct grades designated as AA, A, No. 1, No. 2, and No. 3, qualities based on the presence of certain defects which may be found in glass, that are herein described.

It follows the existing grades of plate glass from which mirrors are made, known as first silvering, second silvering, mirror glazing, glazing, and O. B. qualities.

\section{GENERAL REQUIREMENTS}

All mirrors sold as of commercial standard quality shall be serviceable mirrors equaling or exceeding the quality designated for each grade.

Since the central area of the mirror comes in the direct line of vision, it is of greater importance and, therefore, defects occurring therein are more serious than those appearing in the outer area.

On mirrors to be fitted into frames, small chips on the edge shall not be considered as defects provided they are at least one eighth inch smaller than the width of the frame rabbet.

\section{DETAIL REQUIREMENTS}

The several grades designated below shall comply with the requirements specified. For description of terms see glossary on page 4 and for method of inspection, see page 4.

It is assumed that the majority of mirrors produced will fall under grades No. 1, No. 2, and No. 3. However, for that section of the trade demanding a mirror especially free from defects, the AA quality and A quality may be obtained in limited quantities by special selection.

\section{AA QUALITY}

AA quality mirrors shall be entirely free from major defects and as nearly perfect as it is possible to manufacture them. Only well distributed, fine seed, and small faint hair lines when not grouped shall be permitted. 


\section{A QUALITY}

The central area of mirrors of this quality shall be free from major defects, but may contain well-scattered seed and short faint hair lines, when not grouped, and occasionally very light short finish visible only on close inspection.

The outer area, in addition to the foregoing, may contain seed and short faint scratches when not grouped.

\section{NO. 1 QUALITY}

The central area of mirrors of this quality may contain scattered seed, faint hair lines, and light short finish.

The outer area in addition to the foregoing may contain short scratches and occasional strings not over 2 inches long.

\section{NO. 2 QUALITY}

Mirrors of this quality may contain the following defects: Numerous scattered seed, occasional coarse seed, light reams, strings, light scratches, short finish if not torn, hair lines if not too densely grouped, and bull's eye if not visible from front inspection.

\section{NO. 3 QUALITY}

Mirrors of this quality may contain all the defects which may be found in plate glass.

\section{THICKNESS}

Plate glass mirrors of commercial standard qualities shall be between three-sixteenths and five-sixteenths of an inch thick. If specific thicknesses are ordered a variation of one-thirty-second inch plus or minus the given thickness shall be allowed.

\section{SILVERING}

All commercial standard quality mirrors shall be silvered in an approved manner and guaranteed for a period of one year from the date of manufacture unless the mirrors are subjected to unusual conditions, such as open weather, moist walls, steamed rooms, direct sunlight, or similar conditions.

\section{GUARANTEE}

For the guidance of the buying public, and the protection of the mirror manufacturer, exch commercial standard grade mirror may be labeled in the color designated below, with the following statement for each particular grade:

White.-We guarantee this mirror "AA" quality as specified in Commercial Standard CS27-30 issued by the U. S. Department of Commerce.

(Name of manufacturer.)

Red.-We guarantee this mirror "A" quality as specified in Commercial Standard CS27-30 issued by the U. S. Department of Commerce.

$33426^{\circ}-31-2$ 
Blue.-We guarantee this mirror No. 1 quality as specified in Commercial Standard CS27-30 issued by the U. S. Department of Commerce.

(Name of manufacturer.)

Green.-We guarantee this mirror No. 2 quality as specified in Commercial Standard CS27-30 issued by the U. S. Department of Commerce.

(Name of manufacturer.)

Yellow.-We guarantee this mirror No. 3 quality as specified in Commercial Standard CS27-30 issued by the U. S. Department of Commerce.

(Name of manufacturer.)

\section{METHOD OF INSPECTION}

It is desirable that a uniform method of inspection be followed since the distance from the mirror being examined, the angle between it and the line of sight, and the intensity of light, all affect the visibility of imperfections.

The mirror should be examined in an indirect light of medium intensity with the inspector's eye on a level with the center of the plate and about 36 inches away.

\section{GLOSSARY OF TERMS}

Bubbles.-Gas inclusions, generally spherical and brilliant in appearance and larger than one thirty-second inch in diameter.

Open bubbles: Those which have been broken into by grinding,

leaving a hemispherical hole in the glass surface. Also referred to as shot holes.

Bull's eye.-A wave or depression in the glass causing distortion of the image.

Central area.-That portion of the mirror considered to form an oval or circle centered on the piece, the axes or diameters of which do not exceed 80 per cent of the over-all dimension.

Feathers. - Streaks or areas of finely divided opaque foreign material mixed with numerous small bubbles or seed which appear as a mass of specks. They are due to the inclusion of foreign material in the batch or to incomplete skimming of the pot before pouring.

Fire cracks. - Small cracks penetrating the surface of the plate, usually the shape of short-hooked crescents, caused by sudden heating or chilling of the glass surface.

Hair lines. - Very faint lines on either surface of the glass.

Major defects.- The following are considered major defects: Bubbles bull's eye, fire cracks, feathers, ream, scratches, coarse seed, heavy seed, open seed, short finish, skim, stones, strings, and open bubbles.

Minor defects.-The following are considered minor defects: Fine seed, scattered seed, light short finish, and hair lines.

Ream.-An area of strings or of nonhomogeneous glass incorporated in the plate, appearing as a knotty, hairy mass, mixed with clear glass.

Scratches.-Any marking or tearing of the surface, appearing as though it had been done by either a sharp or rough instrument. 
Seed.-

Seed: Minute bubbles less than one thirty-second inch in diameter. Seed are inherent defects in the best quality of plate glass.

Coarse seed: Minute bubbles between one sixty-fourth inch and one thirty-second inch in diameter.

Fine seed: Minute bubbles less than one sixty-fourth inch in diameter.

Heavy seed: A condition where fine or coarse seed are very numerous, such as 25 or more to the square inch.

Open seed: Those which have been broken into by grinding, leaving a hemispherical hole in the glass surface.

Scattered seed: Indicates a condition of few and occasional easily visible coarse seed. Two or three may be spaced 1 or 2 inches from each other, but one here and there at much greater distances apart is the usual intention of the term.

Short finish.-Poor polish, or improperly finished surface which has the appearance of being slightly pitted and wavy when the surface is viewed in reflected light.

Light short finish: A condition of short finish (insufficient finish, lack of brilliancy) visible only upon close inspection.

Torn short finish: A streaked or blurred short finish.

Skim.- Streaks of dense seed with accompanying small bubbles.

Stones.-Any opaque or partially melted particles of rock, clay, or batch ingredient imbedded in the glass.

Strings.-Light, wavy transparent lines appearing as though a thread of glass had been incorporated into the sheet.

\section{GENERAL CONFERENCE}

Pursuant to a request of the Mirror Manufacturers Association, a general conference of manufacturers, distributors, users, and others interested, was held in Cincinnati, Ohio, on June 12, 1930, to consider the establishment of standards of quality for plate glass mirrors.

The following were present:

Anderson, J. R., National Mirror Works.

BARRon, J. E., Libbey-Owens-Ford Glass Co.

Behm, Carl H., The George Behm \& Sons Co.

Botrs, P. E., Central Glass Co.

Cook, Rosamond C., American Home Economics Association.

Dalberg, F. E., General Fireproofing Co.

Gilmore, WhEELER, Hires Turner Glass Co.

HAAKE, A. P., National Association of Furniture Manufacturers.

HAGEMANN, F. H., Hagemann Bros. Co.

HagemanN, Henry F., Hagemann Bros. Co.

HagemanN, H. R., Hagemann Glass Co.

Hageman, W. B., Hagemann Glass Co.

Hartman, Wm. A., American Mirror Works.

HоввосH, O. J., Hubbuch Glass Co.

Hy mes, F. R., Southeastern Plate Glass Co.

JaY, HaRoLd, Libbey-Owens-Ford Glass Co.

Judson, Frank W., Pittsburgh Plate Glass Co.

Kendue, C. W., Central Glass Co.

Kinselda, P. W., John J. Kinsella Co.

Konen, A. J., Newport Glass, Mirror \& Paint Co.

Lawson, F. H., The F. H. Lawson Co.

MacNichol, Geo. P., jr., Libbey-Owens-Ford Glass Co.

McDonald, WM. H., The Nurre Companies.

Messer, J., Galax Mirror Co.

MURPHY, VINCENT T., Handy \& Harman. 
Smyers, D. W., The Dayton Art Glass Co.

Neuer, H., Neuer Glass Co.

O'BRIEN, Chris. W.

OCHs, J. L., Wisconsin Mirror Plate Co.

Owens, W. H., The Hagemann Glass Co.

Pearson, R. E., American Hotel Association.

Peterson, Emil A., Falconer Plate Glass Corporation.

Rankin, A. M., jr., Consolidated Mirror Co.

REIS, J. H., The American Glass Co.

Springer, Henry R., Showers Bros. Co.

Startsman, D. H., The Wm. Glenny Glass Co.

StzidLe, Harry H., National Bureau of Standards.

Storms, North, Mirror Manufacturers Association.

Stott, Edward M., Stott-Hecht Glass Works.

Surr, A. J., Mid-West Glass Co.

Thieleman, W., jr., Hart Mirror Plate Co.

Watkins, Lum, Newport Glass, Mirror \& Paint Co.

Westcote, Minita, Mirror Manufacturers Association.

Wray, G. W., National Bureau of Standards.

The conference held under the auspices of the division of trade standards, National Bureau of Standards, was presided over by Harry $\mathrm{H}$. Steidle. Fred H. Hagemann, chairman of the association's standardization committee, briefly outlined the desirability of uniform quality standards as a base line of operations for the mirror industry.

The proposed commercial standard grades were thoroughly discussed and numerous changes were made. In a desire to reduce the number of grades it was suggested that $\mathrm{AA}$ and $\mathrm{A}$ qualities be combined, but the concensus of opinion favored the retaining of both grades to take care of the rather small but very discriminating demand for the mirror of superlative grade.

Upon a motion, duly seconded, the conference voted:

To approve the specifications as corrected and to recommend them to the industry for formal acceptance as the standard of quality for the mirror industry.

The question of a guarantee label was next considered and the sentiment of the meeting strongly favored the use of such labels. Dr. A. P. Haake, Managing Director of the National Association of Furniture Manufacturers indicated the desirability of backing up the standard qualities with straight-forward guarantee labels for the guidance of the furniture manufacturers and in this opinion was supported by the others in attendance.

It was suggested that the use of quality guaranteeing labels be made compulsory in the sale of all mirrors purported to be of commercial standard quality, but subsequent discussion indicated that the matter of labeling would adjust itself in time and accordingly, the conference voted:

The guarantee statement read "may be labeled" and the wording for the guarantee and the color of the labels be as revised.

\section{EXPORT TRADE}

It was explained that through the facilities of the Bureau of Foreign and Domestic Commerce, the commercial standard when accepted might be translated into foreign languages and promulgated abroad.

The conference went on record as favoring a thorough trial of the standards in domestic use and recommended that copies of the English edition be sent to the foreign offices of the Bureau of Foreign and Domestic Commerce as a basis of arousing interest in a larger volume of export trade. 


\section{STANDING COMMITTEE AND EFFECTIVE DATE}

A standing committee was appointed to represent the various interests of the mirror industry and to receive all comments and suggestions for the improvement of the commercial standard specifications. No definite interval was fixed for revision of the standard but the committee will meet at the call of the chairman when revision appears necessary.

The standing committee consists of the following:

Fred H. HagemanN, chairman Hagemann Bros. Co., Cincinnati, Ohio.

A. H. Brawner, W. P. Fuller \& Co., San Francisco, Calif.

W. J. Paschal, Paschal Mirror Works, Winston-Salem, N. C.

B. P. Donnelly, Donnelly-Kelley Glass Co., Holland, Mich.

Arthur Dole, jr., Hooker Glass \& Paint Manufacturing Co., Chicago, Ill.

Wheeler Gilmore, Hires Turner Glass Co., Philadelphia, Pa.

WM. B. BANKs, Hart Mirror Plate Co., Grand Rapids, Mich.

A. P. HAAKE, National Association of Furniture Manufacturers, Chicago, Ill.

R. R. RAJ, National Retail Furniture Association, Chicago, I11.

North Storms, Mirror Manufacturers Association, Chicago, Ill.

Mrs. Walter S. Comlt, General Federation of Women's Clubs, Port Chester, N. Y.

Miss Rosamond C. Cook, American Home Economics Association, Cincinnati, Ohio.

HARRY H. Steidle. ex officio secretary, National Bureau of Standards, Washington, D. C.

The conference voted that the commercial standard be made effective for new production 60 days after announcement of the formal acceptance of the standard. Formal acceptance was announced on October 15, and, accordingly, the effective date was set as December $15,1930$.

\section{CERTIFICATION PLAN}

The conference voted its approval of the certification plan for application to mirrors made in accordance with the commercial standard specifications.

The certification plan as applied by the National Bureau of Standards to commercial standards consists in the compilation and distribution of lists of manufacturers who are willing, when requested to do so, to certify to purchasers that products supplied by them comply with all the requirements and tests set forth in nationally recognized commercial standards. The plan is also applied to selected Federal specifications.

These lists are available on request to individual consumers, consumer groups, companies, and in fact to any prospective purchasers, for their guidance.

The benefits now derived from the use of specifications by large consumers are thus made immediately available to the small consumer, with incidental advantage to the larger consumers of convenience in ordering and accepting material with fewer laboratory tests. The manufacturer also benefits from the well-known economies accompany. ing "mass production."

The lists of manufacturers "willing to certify" to the quality of certain commodities are made by corresponding with, as nearly as possible, all the manufacturers of that product and listing only those who signify their willingness to certify to the purchaser, when requested to do so, that the commodities delivered actually comply with the commercial standard. 
Obviously, the purchaser making use of the lists of "willing-tocertify" manufacturers, will select therefrom such manufacturers as are known (or assumed) by him to be reliable.

The trend toward the purchase of materials of certified quality from sources shown on such willing-to-certify lists supplies added incentive to standardization on the part of other producers, and thus the benefits of the certification plan will be felt by purchasers either directly or indirectly, whether or not they make use of the plan themselves.

\section{COMMERCIAL STANDARDS SERVICE}

Industry has long sensed the need for a wider application and use of specifications developed and approved by nationally recognized organizations. To assist these bodies and the producers and consumers in securing this result and as a natural outgrowth of the movement toward elimination of waste through simplified practice, the National Bureau of Standards has set up a procedure under which specifications, properly indorsed, may be printed as official publications of the Department of Commerce and promulgated as "commercial standards." This service parallels that of simplified practice in many respects and is available only upon request.

Broadly speaking, the aim is to continue the same character of cooperative service in this field that is being rendered in simplification. The division of trade standards is not designed to act as a standardizing body, nor will it engage in the preparation of specifications. Its service is mainly promotional in character, since its chief mission is to invite attention to a standard or a specification which any branch of industry may want to promulgate on a nation-wide basis; to determine its eligibility for promulgation; to publish and broadcast it in the event the prerequisites of procedure have been met, including a satisfactory majority acceptance; to facilitate the application of the certification plan for the assurance and convenience of the purchaser; to provide means for periodic audits of adherance; and to cooperate with the Bureau of Foreign and Domestic Commerce in determining the desire of industry relative to translation and promulgation of such specifications as a basis for foreign commerce.

In general, it may be said that a simplification covers types, sizes, and varieties of a commodity which are retained by industry on the basis of demand, whereas a commercial standard establishes definite requirements as to grade, quality or, dimensional tolerances in addition to any limitation of variety desired and accepted by the industry.

\section{ORGANIZATION AND DUTIES OF STANDING COMMITTEE}

In order to carry on the aims and desires of the industry in the standardization of their product, a standing committee is appointed at the general conference. This committee consists of members from each division of the industry, namely, producers, distributors, and consumers, and thus reflects the well-balanced viewpoint of all concerned.

The members of the committee receive all suggestions regarding the commercial standard and consider its revision in the event that such action is desirable and mutually beneficial.

If the commercial standard does not warrant revision, it is reaffirmed in its existing form, but if any important changes are found desirable, 
their adoption is recommended by the committee, whereupon the industry is again solicited for written acceptance of the standard in its revised form.

The committee is in effect a centralizing agency for criticisms and comments regarding the commercial standard and is charged with the responsibility of recommending revisions to keep the standard abreast with current industrial practice.

The proper functioning of the committee requires that, when necessary, its members be willing to attend meetings held at some central place, although in many cases it will be possible to conduct the work by correspondence.

When any deceptions in reference to the commercial standard are reported to the standing committee, it applies moral suasion or such other corrective measures as seem desirable. The Department of Commerce has no "police power" to compel adherence, therefore, it is incumbent upon the standing committee to do all in its power to encourage all divisions of the industry to follow the provisions of the commercial standard and contribute in every way possible to its general adoption and usefulness.

\section{YOUR COOPERATION}

As a producer, distributor, or consumer of some of the commodities for which commercial standards have already been established, you are in a position to avail yourself of the benefits arising from the use of quality standards and incidentally to add impetus to this method of eliminating waste.

The first step is a declaration in favor of the standard by recording your intention to adhere, as closely as circumstances will allow, to the standards for those products which you may buy or sell.

The receipt of your signed acceptance will permit the listing of your company in new editions of the commercial standards that you accept.

You will, of course, want to examine any commercial standards before signing a formal acceptance. The National Bureau of Standards will, therefore, furnish a copy of any standard under consideration for acceptance. To facilitate this procedure, a list appears on page 14 that may be checked and mailed to the division of trade standards, Bureau of Standards, Washington D. C. The publications may also be secured singly or in quantities at a nominal price from the Government Printing Office. Prices will be furnished upon request.

The acceptance of a commercial standard is an entirely voluntary action and applies to the production, sale, and use of stock items. It is not meant to interfere with the introduction, manufacture, or sale of special sizes and types sometimes required.

Trade associations and individual companies often distribute large numbers of the printed standard for the information and guidance of their members or customers. In such cases it is possible to extend the scope and degree of adherence by urging each recipient to send in an acceptance, bearing in mind that the practical value of any standardization is measurea by the observance it receives.

An acceptance form for the commercial standard herein covered is included on page 11. 



\section{ACCEPTANCE OF COMMERCIAL STANDARD}

(Please sign and Return This Sheet to Division of Trade Standards, National Bureau of Standards, Washington, D. C.)

Date

Division of Trade Standards, National Bureau of Standards, Washington, D.C.

Gentlemen: We, the undersigned, do hereby accept the original draft of the commercial standard, as our standard practice in the $\left\{\begin{array}{l}\text { production }^{1} \\ \text { distribution }^{1} \\ \text { use }^{1}\end{array}\right\}$ of plate glass mirrors, beginning (Date) , and will use our best effort in securing its general adoption.

To permit intelligent review of the effectiveness of the commercial standard every year by an accredited committee of all interests, working in cooperation with the Department of Commerce, we plan to supply all data, upon request, which may be necessary for the development of constructive revisions. It is understood that any suggested modifications will be submitted as soon as formulated, and shall not be promulgated until accepted in form similar to this recommendation.

Signature

(Kindly typewrite or print the following lines)

Title

Company -

Street address

City and State

We are members of the following associations or other organizations interested in the production, sale, or use of plate glass mirrors. the case of related interests, trade papers, colleges, etc. desiring to record their general approval the words "in principle" should be added after the signature. 


\section{TO THE ACCEPTOR}

In signing the acceptance blank, please bear the following points clearly in mind:

1. Adherence.-The Department of Commerce has no regulatory powers to enforce adherence to the commercial standards. Instead, this waste-elimination program is based on voluntary cooperation and self-government in industry. To make this specific standardization operate as a satisfactory example of self-government, it is highly desirable that it be kept distinct from any plan or method of governmental regulation or control. It will be successful according to the degree to which manufacturers, distributors, and purchasers adhere to its terms and conditions.

2. The industry's responsibility.-The department cooperates only on the request of the industry, and assumes no responsibility for industrial acceptance or adherence. This program was developed by the industry on its own initiative. Its success depends wholly on the active cooperation of those concerned.

3. The acceptor's responsibility.-You are entering into an entirely voluntary arrangement, whereby the members of the industry-the distributors and consumers of the product, and others concernedhope to secure the benefits inherent in commercial standardization. Those responsible for this standard realize that instances may occur in which it will be necessary to supply or purchase items not included therein. The purpose is however, to secure wider support for nationally recognized standards covering grade, quality, and other characteristics of products. Consumers can make the program a success if, in their purchasing, they will make a definite and conscientious effort to specify in terms of this commercial standard.

4. The department's respansibility.-The function performed by the Department of Commerce is fourfold: First, to act as a referee to insure adequate consideration of the needs of all interests; second, to supply such assistance and advice in the development of this program as past experience with similar programs may suggest; third, to solicit and record the extent of adoption and adherence to the standard; and fourth, to add all possible prestige to this standardization movement by publication and promulgation if and when it is adopted and accepted by all elements directly concerned. 


\section{REQUEST FOR COMMERCIAL STANDARDS}

\section{Date}

\section{Division of Trade Standards,}

National Bureau of Standards,

Washington, D. C.

Gentlemen: The undersigned wishes to examine the commercial standards checked on the reverse side of this page, with a view toward accepting them as our standard of practice in the production, distribution, or consumption of the standardized lines.

Signed

(Kindly typewrite or print the following lines)

Title

Company

Street address

City and State 


\section{COMMERCIAL STANDARDS}

CS No.

Item

0-30. The commercial standards service and its value to business.

1-28. Clinical thermometers.

2-30. Mop sticks.

3-28. Stoddard solvent.

4-29. Staple porcelain (all-clay) plumbing fixtures.

5-29. Steel pipe nipples.

6-29. Wrought-iron pipe nipples.

7-29. Standard weight malleable iron or steel screwed unions.

8-30. Plain and thread plug and ring gage blanks.

9-29. Builders' template hardware.

10-29. Brass pipe nipples.

11-29. Regain of mercerized cotton yarns.

12-20. Domestic and industrial fuel oils.

13-30. Dress patterns.
CS No.

Item

14-31. Boys' blouses, button-on waists, shirts and junior shirts (in preparation).

15-29. Men's pajamas.

16-29. Wallpaper.

17-30. Diamond core drill fittings.

18-29. Hickory golf shafts.

19-30. Foundry patterns of wood.

20-30. Staple vitreous china plumbing fixtures.

21-30. Interchangeable ground glass joints.

22-30. Builders' hardware (nontemplate).

23-30. Feldspar.

24-30. Standard screw threads.

25-30. Special screw threads.

26-30. Aromatic red cedar closet lining.

27-30. Plate-glass mirrors.

14 